\title{
DIASPORAS TĪKLOŠANĀS PRAKSES UN PIESAISTES FAKTORI MŪSDIENĀS
}

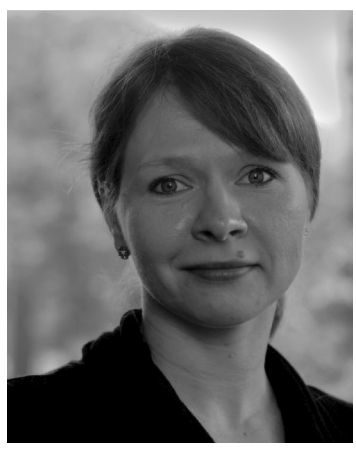

\begin{abstract}
Inta Mieriṇa ir Latvijas Universitātes (LU) Sociālo zinātṇu fakultātes asociētā profesore, LU vadošā pētniece un Diasporas un migrācijas pētījumu centra direktore. Viṇas specializācija ir politiskā sociologijija, un viņas nesenie pētījumi koncentrējas uz jaunajiem migrācijas veidiem un migrantu un etnisko minoritāšu integrāciju. Autore ir piedalījusies daudzos starptautiskos pētījumos un vadījusi vairākus migrācijas projektus, ieskaitot lielāko latviešu emigrantu aptauju, kas ir sasniegusi 14068 latviešus 118 valstīs. Viṇai ir publikācijas tādos žurnālos kā Social Science Research, The Sociological Review, European Societies, Europe-Asia Studies, un viņa ir Springer apgāda grāmatas par latviešu emigrantu kopienām līdzredaktore (2019). I. Mieriṇa regulāri sniedz ieteikumus par migrācijas un integrācijas jautājumiem politikas veidotājiem Latvijā un ir arī Eiropas Komisijas projektu vērtēšanas eksperte.
\end{abstract}

Raksturvārdi: diaspora, migrācija, sabiedriskā līdzdalība, diasporas organizācijas, jaunieši.

\section{Ievads}

Stipras latviešu kopienas ārvalstīs pamats ir tās saliedētība un pastāvīga kontaktu uzturēšana starp diasporas locekḷiem, iesaistoties diasporas pasākumos, organizācijās un grupās ${ }^{1}$. Diemžēl vāji attīstītas līdzdalības kultūras dēl Latvijas emigrantu iesaiste organizācijās kopumā ir zema². İpaši liels izaicinājums ir iespējas iekḷaut Latvijas diasporas kopienā mazākumtautību pārstāvjus, kurus mazāk interesē tradicionālās diasporas organizāciju aktivitātes. Otra grūtāk piesaistāmā grupa ir diasporas jaunieši; tradicionālajās Latvijas diasporas mītnes zemēs organizāciju kodolu bieži vien veido vecākās paaudzes pārstāvji. N̦emot vērā minētos apsvērumus, šî pētījuma mērkis ir atbildēt uz jautājumu, kas veicinātu diasporas pārstāvju (t. sk. jauniešu un mazākumtautību pārstāvju) plašāku līdzdalību diasporas dzīvē. Pētîjums veikts ar Latvijas Zinātnes padomes finansiālu atbalstu granta Labklājības un sociālās integrācijas izpēte likvīdās migrācijas kontekstā: longitudinālā pieeja (Nr. LZP-2018/ 1-0042) ietvaros.

\section{Dati un metodoloǵija}

Pētījumā izmantotas vairākas metodes. Pirmajā pētījuma posmā sniegta detalizēta kvantitatīva informācija par dažādu diasporas pārstāvju līdzdalību, kas balstīta uz aptaujas Latvijas emigrantu kopienas I viḷna (2014) datiem un aptver 14068 respondentus 118 valstīs, ieskicējot arī izmaiņas, kas vērojamas II viḷna (2019) datos. Analīzē izmantoti statistiski svērti dati ${ }^{3}$, nodrošinot, ka respondentu vecuma,

\footnotetext{
3 Goldmanis 2015.
} 
dzimuma, tautības, izglītības un mītnes zemes sadalījums izlasē atbilst tam, kas vērojams ǵenerālajā kopumā, kurš ḷauj vispārināt aptaujas rezultātus. Lai labāk izprastu, kuri faktori ir noteicošie, skaidrojot diasporas pārstāvju piedalīšanos diasporas organizācijās un pasākumos, izmantota loǵistiskā regresija. Regresiju modeḷi atspoguḷoti 1. tabulā. Trūkstošo vērtību dēḷ (ne visi respondenti pilnībā atbildējuši uz visiem jautājumiem), modeļi balstīti uz attiecīgi 7117 (M1) un 7162 respondentiem. (M2) Hosmera un Lēmešova tests liecina, ka abi modeḷi uzskatāmi par uzticamiem (Sig. < 0,05). Regresijas modelī iekḷautie neatkarīgi mainīgie izskaidro $51 \%$ variācijas līdzdalībā diasporas organizācijās (Nagelkerkes $\mathrm{R}^{2}=0,511$ ) un 38\% variācijas līdzdalībā diasporas pasākumos.

Otrajā pētîjuma posmā izmantotas kvalitatīvās pētījumu metodes, iegūstot padziḷinātu izpratni par līdzdalības motivāciju vai šḳēršliem. Īpaša uzmanība pievērsta divām lielākajām Latvijas diasporas mītnes zemēm - Lielbritānijai un Vācijai. N̦emot vērā, ka lielākā daļa Latvijas diasporas pārstāvju ir jaunieši ${ }^{4}$, taču vingu iesaiste diasporas dziviē ir salīdzinoši maza, tika veiktas piecas fokusa grupu diskusijas (turpmāk - FGD) ar diasporas jauniešiem 18-35 gadu vecumā Berlīnē, Minsterē, Londonā, Bredfordā un Straumēnos. Diskusijas dalībnieku skaits bija no septiniem līdz 10 cilvēkiem, jo tas l̦auj sasniegt viedokḷu daudzveidību, vienlaikus nodrošinot diskusiju efektivitāti un ikvienam sniedzot iespēju izteikties. Diskusijās izmantotas dažādas inovatīvas metodes, t. sk. projektīvā tehnika, lai izzinātu asociācijas ar diasporas organizācijām, argumentu izkristalizēšanas metode, kā arī nākotnes darbgrupas (future workshops), kurās tika raksturota "ideālā" diasporas organizācija un aplūkoti dažādi diasporas iesaistes un attīstības scenāriji. Diskusijās piedalījās gan jaunieši, kuri ir iesaistījušies diasporas grupās vai organizācijās, gan jaunieši, kuri tajās nav iesaistījušies. Ar pētījuma dalībnieku atḷauju tika veikts diskusijas audio ieraksts. Tā kā krievu jauniešu skaits FDG bija neliels, tika veiktas papildu intervijas tieši ar šīs grupas jauniešiem.

4 Mierina et al. 2017; Mieriņa 2019.

\section{Diasporas pārstāvju līdzdalība diasporas pasākumos un organizācijās}

Līdz šim apjomīgākā Latvijas diasporas aptauja Latvijas emigrantu kopienas: nacio$n \bar{a} l \bar{a}$ identitāte, transnacionālās attiecības un diasporas politika pirmo reizi l̦āva iegūt uzticamus datus par to, kāda daļa Latvijas diasporas pārstāvju ir iesaistījušies diasporas organizācijās un citās aktivitāšu formās. Aptauja atklāj, ka visbiežākais veids, kā ārzemēs dzīvojošie latvieši iesaistās diasporas dzīiē, ir ārzemēs dzīvojošo latviešu ziṇu portālu lasīšana. Kopumā šādus portālus (Latviansonline.com, Baltic-ireland.ie u. c.) lasa 40\% diasporas pārstāvju (1. attēls), taču gandrīz puse no viniem to dara loti reti - retāk nekā reizi mēnesī. Par regulāriem ārzemēs dzīvojošo latviešu ziṇu portālu lietotājiem var uzskatīt ap 20\% diasporas pārstāvju. Arī nākamā izplatītākā diasporas iesaistes forma ir saistīta ar interneta vidi. Katrs ceturtais (26\%) ārvalstīs dzīvojošais Latvijas diasporas pārstāvis piedalās kādā diasporai domātā vēstkopā, blogā vai domubiedru grupā (piem., Latvieši Londonā Draugiem.lv u. c.), turklāt šāda veida līdzdalībai ir tendence pieaugt. Līdzīgs skaits (24\%) pēdējā gada laikā ir piedalījies kādā ārzemēs dzīvojošajiem latviešiem domātā pasākumā (piem., koncertā, tikšanās pasākumā, sanākšanā). $22 \%$ savā pašreizējā mītnes zemē ir apmeklējuši publiskus Jāṇu pasākumus vai Latvijas Neatkarības proklamēšanas dienas 18. novembra - svinību pasākumus. $16 \%$ diasporas pārstāvju, kuriem ārzemēs ir bērni, šie bērni apmeklēja vai bija apmeklējuši latviešu nedēlas nogales skolu. 11\% Latvijas diasporas pārstāvju ir iesaistījušies diasporas organizācijās, tomēr jāatzīst, ka salīdzinājumā ar citām Centrāleiropas un Austrumeiropas valstīm šis diasporas organizētības rādītājs nav slikts un tam ir tendence pieaugt.

Diasporas pārstāvji, kuri ir aktīvi, parasti ir iesaistījušies vairākās dažādās aktivitātēs, bet tie, kuri nav, neiesaistās nevienā. Tā, piem., $40 \%$ diasporas pārstāvju nav nekādā veidā iesaistījušies diasporas dzīiē. Vēl $26 \%$ ir iesaistîjušies tikai vienā no aktivitātēm - visbiežāk lasa diasporai domātos portālus $(50 \%)$ vai blogus/vēstkopas (26\%). Neskaitot aktivitātes internetā, diasporas dzīiē kaut vienā veidā ir 
iesaistījušies 35\% ārvalstīs dzīvojošo latviešu vai Latvijas valstspiederīgo. Vairāki līdzdalības veidi diasporas dz̄ivē (piem., ārzemēs dz̄̄vojošo latviešu ziņu portālu lasīšana, dalība diasporas pasākumos, mākslinieciskās pašdarbības vai citās neformālās grupās) pieaug, kad cilvēks ārzemēs pavadījis ilgāku laiku.

Taču visvairāk piedalīšanās diasporas dzīvē ir atkarīga no etniskās piederības. Latvieši ir visaktīvākie dalībnieki visdažādākajās aktivitātēs: gandrīz puse (49\%) lasa diasporas ziṇu portālus, trešdaḷa piedalās kādā Latvijas emigrantu un diasporas vēstkopā, blogā vai grupā internetā, un tikpat daudz latviešu pēdējā gada laikā ir piedalījušies diasporas latviešiem domātos pasākumos (2. attēls). $20 \%$ no tiem diasporas pārstāvjiem, kuriem ir bērni, šie bērni apmeklēja vai bija apmeklējuši latviešu nedēlas nogales skolas, 13\% bērns piedalījās kādā latviešu interešu grupā (korī vai tml.), bet $10 \%$ pats respondents vai respondenta bērni bija piedalījušies diasporas nometnēs. Mākslinieciskās pašdarbības grupā darbojās 6\% latviešu, bet $9 \%$ latviešu bija izvēlējušies citu neformālu interešu grupu, kur pulcējas Latvijas izcelsmes cilvēki. Tas liecina, ka mākslinieciskās pašdarbības grupas nebūt nav biežākais ārzemēs dzīvojošo kopīgo aktivitāšu veids.

No Latvijas izcel̨ojušo krievu iesaistīšanās diasporas dzīvē ir pavisam niecīga: diasporas organizācijās iesaistījušies tikai $2 \%$ krievu tautības emigrantu salīdzinājumā ar 16\% latviešu, un tikai 7\% pēdējā gada laikā apmeklējuši kādus diasporai domātus pasākumus. Kopumā 93\% diasporas organizāciju biedru ir latvieši, bet tikai 5\% - krievu. Diasporas pasākumus apmeklē $89 \%$ latviešu un tikai $9 \%$ krievu. Biežākās krievu tautības emigrantu aktivitātes noris internetā: $26 \%$ lasa diasporas ziņu portālus un $14 \%$ piedalās kādā emigrantu vēstkopā vai grupā, kurās bieži vien risina praktiskus jautājumus vai apmainās ar informāciju.

Pētījums l̦auj gūt ieskatu arī diasporas organizāciju un pasākumu dalībnieku profilā. Puse diasporas organizāciju dalībnieku ir vecās diasporas pārstāvji un puse - jaunās diasporas pārstāvji, bet no diasporas pasākumu apmeklētājiem $75 \%$ ir jaunās diasporas pārstāvji. Nedaudz vairāk nekā puse (56\%) diasporas organizāciju dalībnieku dz̄ivo ASV, Kanādā, Austrālijā vai Jaunzēlandē - ievērojami lielāka proporcija nekā diasporā kopumā. Diasporas organizāciju dalībnieku vecums ḷoti atšķiras
Lasa ārzemēs dzīvojošo latviešu ziṇu portālus Ir biedrs kādā diasporas vēstkopā/ blogā/ domubiedru grupā

Piedalījās kādā ārzemēs dzīvojošajiem latviešiem domātā pasākumā

Atzīmējis/-usi Jāṇus vai 18. novembri mītnes zemē

Bērns apmeklē vai ir apmeklējis latviešu nedēlas nogales skolu

Diasporas organizācijas biedrs

Bērns piedalās kādā latviešu interešu grupā

Pats vai bērns (-i) piedalījies diasporas nometnē

Ir neformālā interešu grupā, kur pulcējas Latvijas izcelsmes cilvēki

Ir ārzemēs dzīvojošo latviešu mākslinieciskās pašdarbības grupā

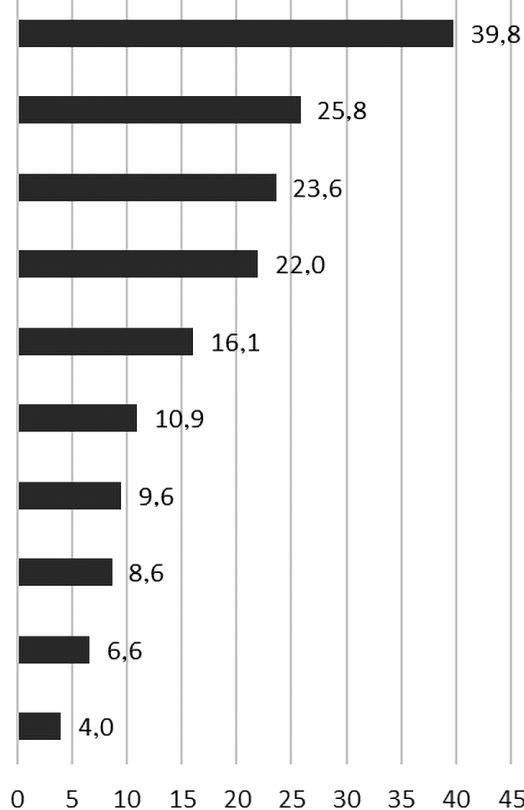

45

1. attēls. Iesaistīšanās Latvijas diasporas dzīvē (\%) 


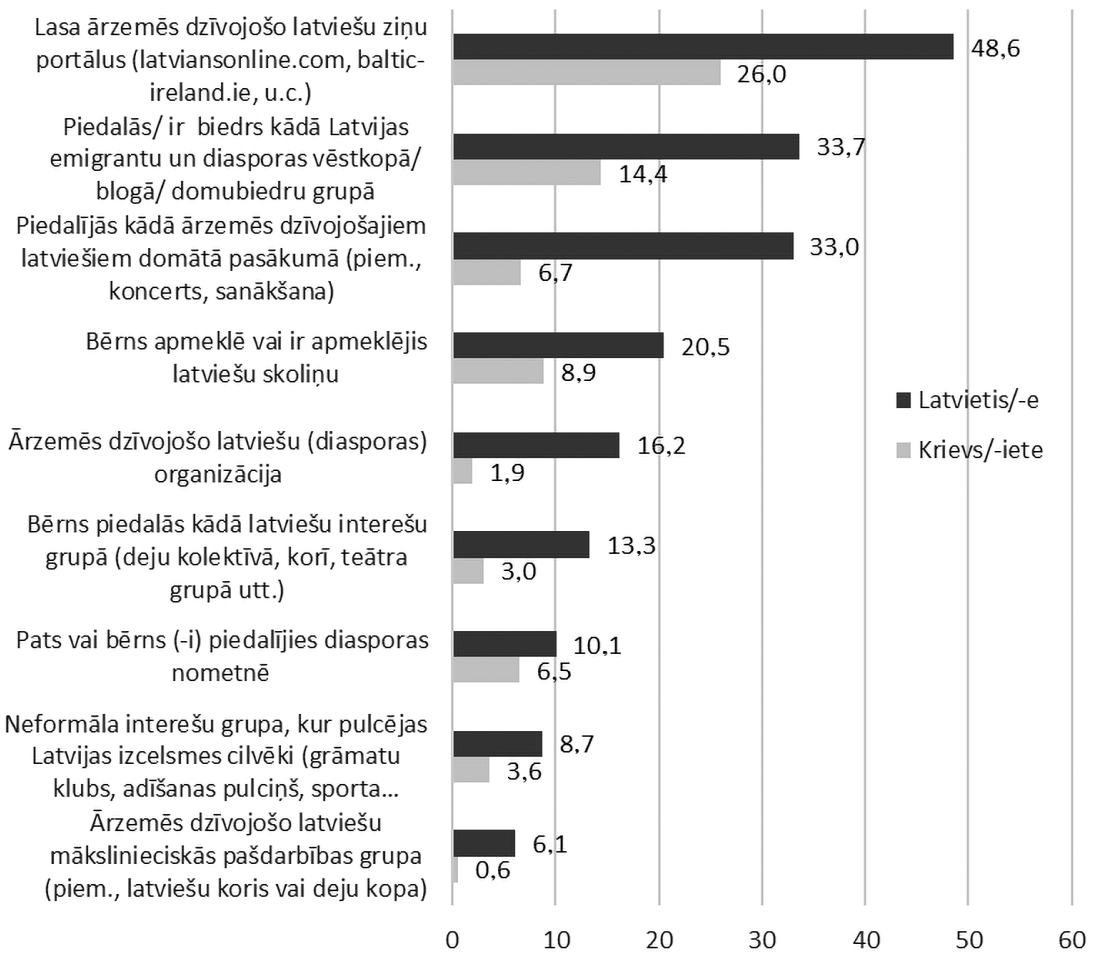

2. attēls. Dažādu etnisko grupu iesaistīšanās Latvijas diasporas dzīvē (\%)

atkarībā no valsts. ASV, Kanādā, Jaunzēlandē un Austrālijā liela daḷa organizāciju dalībnieku ir 65 gadus veci un vecāki, tomēr organizācijās ir redzama arī jaunā paaudze: $28 \%$ ir vecumā līdz 35 gadiem. Arī NVS valstīs un Gruzijā liela daḷa diasporas organizāciju pārstāvju ir virs vidējā vecuma, taču šajās valstīs diemžèl ir redzama paaudžu nomaiņas problēma: tikai $17 \%$ ir vecumā līdz 35 gadiem. Diasporas organizācijās Vācijā pārstāvētas daudzas paaudzes, bet citās Rietumvalstīs un arī Ziemeḷvalstīs diasporas organizācijās pārsvarā darbojas jauni cilvēki. Piem., Apvienotajā Karalistē $62 \%$ diasporas organizāciju pārstāvju ir vecumā līdz 35 gadiem. Organizācijas labāk spējušas piesaistīt cilvēkus ar augstāko izglītību: $71 \%$ diasporas organizāciju pārstāvju ir ar augstāko izglītību, 21\% - ar vidējo un tikai $8 \%$ ir zemākais izglītības līmenis.

\section{Līdzdalību ietekmējošie faktori}

No iesaistīšanās diasporas organizācijās visvairāk attur intereses trūkums (38\%), brīvā laika trūkums (28\%) un informācijas trūkums par šādām organizācijām (24\%), kam seko grūtības nokḷūt līdz pulcēšanās vietai un pārliecības trūkums, ka tas ir domāts "tādiem cilvēkiem kā es” (14\%) . Protams, jāņem vērā, ka šie faktori ir saistīti. Kā norāda jaunieši fokusa grupu diskusijās, ja ir interese, informāciju var atrast.

Vecās diasporas pārstāvji (trimdas latvieši un to pēcteči), kas sevi saista ar Latviju, ievērojami biežāk nekā jaunās diasporas pārstāvji iesaistās gan diasporas organizācijās, gan diasporas pasākumos un latvietību bieži vien cenšas uzturēt arī savos bērnos un mazbērnos. Visaktīvāk diasporas dzīvē iesaistās latvieši, kas dzimuši ārpus Latvijas ${ }^{6}$. Tradīcijas aktīvi ir uzturējušas diasporas organizācijas tipiskajās vecajās mītnes zemēs, taču ir bažas, ka

5 Mierina 2016.

6 Protams, jāṇem vērā, ka daḷa ārpus Latvijas dzimušo zaudē saikni ar Latviju un neuzskata sevi par latviešiem - šādā gadījumā vinii mūsu statistikā neparādīsies. 
līdz ar paaudžu nomaiņu, nemainoties pašām organizācijām un nepieskaṇojoties jaunajiem apstākḷiem, tās var kḷūt mazāk aktuālas. Aptaujas dati liecina, ka jaunās diasporas pārstāvjiem biežāks iemesls neiesaistīties ir tas, ka diasporas organizācijas vienkārši neinteresē (39\%) vai trūkst brīvā laika (29\%), t. i., trūkst pārliecinošas motivācijas, kādēḷ iesaistīties. Diasporas organizāciju mazāka popularitāte jaunās diasporas vidū iet roku rokā ar to, ka starp nesenajiem emigrantiem biežāk sastopami Latvijas mazākumtautību pārstāvji. Regresiju analīzes rezultāti (tabula) liecina, ka, kontrolējot pārējo faktoru ietekmi, iespēja, ka latvieši iesaistīsies diasporas organizācijās, ir 6,8 reizes augstāka nekā iespēja, ka to darīs citu tautību pārstāvji. Biežākais iemesls, kādēl krievi neiesaistās diasporas organizācijās, ir, ka viņus tas neinterese $\bar{e}^{7}$. Aptuveni trešdaḷa atzīst, ka nav nemaz par tādām dzirdējuši.

No dalības diasporas organizācijās un pasākumos var atturēt ne tikai tautība, bet arī valoda. Kā liecina aptauja Latvijas emigrantu kopienas, 9\% diasporas pārstāvju, kas uzskata sevi par latviešiem, ir vidējas, vājas latviešu valodas zināšanas vai to nav nemaz. Otrkārt, daudziem ir dzīvesbiedrs, kas nav latvietis un latviski nerunā. Šādi cilvēki ārpusinterneta diasporas aktivitātēs un pasākumos iesaistās vidēji divreiz retāk nekā tie, kuru dzīvesbiedrs ir latvietis. Ja diasporas pasākumu apmeklēšana citas tautības dzīvesbiedriem nav pietiekami saistoša, tas attur no piedalīšanās abus partnerus. Treškārt, FGD liecina, ka diasporas pārstāvji labprāt iepazīstinātu ar latviešu kultūru un pasākumiem ar̄̄ savus ārzemju draugus. Diemžēl šobrīd, kā norāda jaunieši, no iesaistīšanās organizācijās attur latviešu atvērtības trūkums - ne tikai pret citu tautību izceḷotājiem no Latvijas, bet arī pret citu tautību cilvēkiem kopumā, kā arī pret vienkārši atšksirīgo.

Liela nozīme ir arī ǵeogrāfiskajam faktoram. ASV, Kanādā, Jaunzēlandē un Austrālijā

Jurkāne-Hobein, Kḷave 2019. iespēja, ka diasporas pārstāvis būs iesaistījies diasporas organizācijā, ir 4,7 lielāka nekā Apvienotajā Karalistē. Tas, visticamāk, saistīts ar labi iesakņojušos diasporas organizāciju tīklu, pulcēšanās vietām, struktūru un pieredzi. Arī Ziemeḷvalstīs iespēja iesaistīties diasporas organizācijās ir ievērojami lielāka nekā Apvienotajā Karalistē. To var ietekmēt gan valsts atbalsts mazākumtautību aktivitātēm, kas nereti pieejams Ziemel̦valstīs, gan arī kopumā aktīvāka pilsoniskā kultūra šajās sabiedrībās. Dienvideiropas valstīs, savukārt, varbūtība iesaistīties diasporas organizācijās ir vismaz trīs reizes mazāka nekā Lielbritānijā. Šajās valstīs latviešu skaits ir salīdzinoši neliels un lielā izkaisītība un salīdzinoši mazais diasporai domāto pasākumu un organizāciju skaits var kavēt iesaisti diasporas dzīvē. To, ka ir grūti nokḷūt līdz aktivitāšu norises vietai, visbiežāk par šķērsli minējuši Austrumeiropā, kā arī ASV, Kanādā, Austrālijā un Jaunzēlandē dzīvojošie (22\%), kur uz pasākumiem vai aktivitātēm nereti jāmēro liels attālums.

Nozīme ir arī apdzīvotās vietas tipam. Ciematos vai laukos dzīvojošie iesaistījušies diasporas organizācijās un pasākumos divarpus reižu retāk un mazpilsētu iemītnieki aptuveni divas reizes retāk nekā galvaspilsētā dz̄ivojošie. Arī citās lielajās pilsētās dzīvojošajiem iespēja iesaistîties diasporas organizācijās un pasākumos ir nozīmīgi mazāka nekā galvaspilsētā. Papildu informācijas trūkuma lielākais škēēslis ir attālums.

Loti nozīmīgs faktors, kas ietekmē iesaisti diasporas dzīvē, ir piederības izjūta citiem cilvēkiem no Latvijas ārvalstīs, tomēr nevar izslēgt abpusēju saistību, t. i., ka līdzdalība veicina piederības sajūtu gan citiem cilvēkiem no Latvijas ārvalstīs, gan Latvijai kopumā. Katrā ziņā, stiprinoties piederības sajūtai kopienai un valstij, arī iesaiste diasporas dzīvē palielinātos. Vismazāk diasporas dzīvē iesaistās tie, kuri emigrējuši tāpēc, ka nepatika Latvijā notiekošie procesi, politiskā vide, nevarēja atrast darbu un neredzēja sev nākotni Latvijā. Tāpat mazaktīvi ir tie, kas Latvijā bija neapmierināti ar sociālo un finansiālo nodrošinājumu. Aktīvākie turpretī ir emigranti, kas aizbraukuši vai nu pozitîvas motivācijas dēḷ: lai studētu, gūtu jaunus iespaidus, vai tādēl, ka iepazinušies ar ārzemnieku. 
Tabula. Līdzdalību diasporas organizācijās un pasākumos ietekmējošie faktori

\begin{tabular}{|c|c|c|c|c|c|c|c|c|}
\hline & \multicolumn{4}{|c|}{$\begin{array}{c}\text { M1 }(n=7117) \\
\text { Līdzdalība diasporas } \\
\text { organizācijās }\end{array}$} & \multicolumn{4}{|c|}{$\begin{array}{c}\text { M2 }(n=7162) \\
\text { Līdzdalība diasporas } \\
\text { pasākumos }\end{array}$} \\
\hline & B & S. E. & Sig. & $\operatorname{Exp}(B)$ & B & S. E. & Sig. & $\operatorname{Exp}(B)$ \\
\hline Vecums (ref. 15-24) & & &, 000 & & & &, 002 & \\
\hline $25-34$ &,- 018 &, 184 & ,922 & ,982 &,- 022 &, 110 & ,842 & ,978 \\
\hline $35-44$ &, 084 & ,210 & ,689 & 1,088 &, 011 &, 131 & ,932 & 1,011 \\
\hline $45-54$ &, 257 & ,229 & ,261 & 1,293 & ,377 & , 143 & ,009 & 1,458 \\
\hline $55-64$ & ,898 & ,241 &, 000 & 2,454 & ,326 &, 171 &, 057 & 1,386 \\
\hline $65+$ & 1,407 & ,355 &, 000 & 4,084 & ,741 & ,297 & ,013 & 2,098 \\
\hline Latvietis (-e) & 1,921 & ,271 &, 000 & 6,831 & ,628 & ,214 &, 003 & 1,874 \\
\hline Krievs (-iete) &,- 303 & ,260 & ,245 &, 739 & $-1,106$ & ,214 &, 000 & ,331 \\
\hline Cita tautība & ,882 & ,271 & ,001 & 2,415 &,- 269 & ,223 & ,226 &, 764 \\
\hline Dzimums (sieviete) &, 150 &, 115 & 194 & 1,162 & , 105 & ,078 & ,176 & 1,111 \\
\hline Izglītības līmenis (ref. zems) & & &, 000 & & & &, 000 & \\
\hline Vidējs &, 087 & ,192 & 650 & 1,091 &, 031 & , 108 & ,776 & 1,031 \\
\hline Augsts &, 720 &, 189 &, 000 & 2,055 &, 509 &, 110 &, 000 & 1,664 \\
\hline $\begin{array}{l}\text { Izcelošananas g. (ref. visu mūžu } \\
\text { ărpus LV) }\end{array}$ & & &, 000 & & & &, 000 & \\
\hline Pirms 1991.g. &,- 228 & ,247 & ,355 & ,796 &,- 895 &, 238 &, 000 & ,409 \\
\hline 1991-1999 & $-3,126$ & 610 &, 000 & 044 & $-2,020$ &, 314 &, 000 & ,133 \\
\hline 2000-2003 & $-3,670$ & ,620 &, 000 &, 025 & $-2,328$ & ,313 &, 000 &, 097 \\
\hline 2004-2008 & $-3,706$ & ,605 &, 000 & 025 & $-2,222$ & ,301 &, 000 & , 108 \\
\hline 2009-2011 & $-3,787$ & ,603 &, 000 &, 023 & $-2,234$ &, 300 & ,000 &, 107 \\
\hline Pēc 2011. g. & $-3,749$ & 600 &, 000 & ,024 & $-2,383$ & ,298 &, 000 &, 092 \\
\hline $\begin{array}{l}\text { Valsts (ref. Apvienotā } \\
\text { Karaliste) }\end{array}$ & & &, 000 & & & &, 000 & \\
\hline Vācija &,- 022 & ,236 & ,925 & ,978 &,- 075 &, 133 & ,572 & ,928 \\
\hline İrija & ,319 & ,273 & ,243 & 1,376 &, 519 &, 138 &, 000 & 1,681 \\
\hline Norvēgija &, 532 & ,320 & ,097 & 1,703 & ,029 & ,198 &, 882 & 1,030 \\
\hline $\begin{array}{l}\text { ASV, Kanāda, Austrālija, } \\
\text { Jaunzēlande }\end{array}$ & 1,544 & , 163 &, 000 & 4,685 & ,978 &, 104 &, 000 & 2,659 \\
\hline $\begin{array}{l}\text { Ziemel̦valstis, izṇemot } \\
\text { Norvègiju }\end{array}$ & 1,187 & ,224 &, 000 & 3,278 &, 140 &, 161 & ,385 & 1,150 \\
\hline NVS valstis un Gruzija &,- 445 & ,276 & ,107 & ,641 & $-1,526$ &, 210 &, 000 & ,217 \\
\hline Dienvideiropas valstis & $-1,220$ & ,618 &, 049 & ,295 & $-1,511$ & ,322 &, 000 & ,221 \\
\hline $\begin{array}{l}\text { Rietumeiropas valstis, iznemot } \\
\text { Lielbritāniju, Vāciju un İriju }\end{array}$ & ,816 & ,232 &, 000 & 2,261 & ,262 & 157 & ,095 & 1,300 \\
\hline Austrumeiropas valstis (ES) &,- 190 & ,348 &, 586 &, 827 & ,196 &, 214 & ,358 & 1,217 \\
\hline Pārējās valstis & 1,803 & ,315 &, 000 & 6,068 & ,318 &, 264 & ,229 & 1,374 \\
\hline $\begin{array}{l}\text { Nodarbošanās (ref. algots } \\
\text { darbinieks) }\end{array}$ & & &, 000 & & & &, 001 & \\
\hline Uzṇēmējs, darba devējs &,- 278 & ,259 & ,284 & ,757 & ,261 &, 180 &, 148 & 1,298 \\
\hline $\begin{array}{l}\text { Pašnodarbinātais / nodarbināts } \\
\text { gimenes uzņēmumā }\end{array}$ &, 141 &, 215 &, 512 & 1,152 & ,255 &, 151 & ,091 & 1,291 \\
\hline
\end{tabular}




\begin{tabular}{|c|c|c|c|c|c|c|c|c|}
\hline & \multicolumn{4}{|c|}{$\begin{array}{c}\text { M1 }(n=7117) \\
\text { Līdzdalība diasporas } \\
\text { organizācijās }\end{array}$} & \multicolumn{4}{|c|}{$\begin{array}{c}\text { M2 }(n=7162) \\
\text { Līdzdalība diasporas } \\
\text { pasākumos }\end{array}$} \\
\hline & B & S. E. & Sig. & $\operatorname{Exp}(B)$ & B & S. E. & Sig. & $\operatorname{Exp}(B)$ \\
\hline $\begin{array}{l}\text { Nestrādāju un aktīvi meklēju } \\
\text { darbu }\end{array}$ &, 826 & ,352 & ,019 & 2,285 & ,739 &, 242 & ,002 & 2,094 \\
\hline Studijas, mācības & ,716 & ,297 & ,016 & 2,046 &, 566 & , 197 &, 004 & 1,762 \\
\hline $\begin{array}{l}\text { Prakse, apmaiņa, prof. piere- } \\
\text { dzes ieguve }\end{array}$ & 1,322 &, 500 &, 008 & 3,750 & ,907 & ,361 &, 012 & 2,477 \\
\hline $\begin{array}{l}\text { Bērna kopšana vai citu gim. } \\
\text { locekḷu aprūpe }\end{array}$ &,- 273 &, 315 & ,386 &, 761 & ,206 & , 197 & ,295 & 1,229 \\
\hline Pensija & 686 & ,363 & ,059 & 1,986 & ,474 & ,304 &, 120 & 1,606 \\
\hline Nestrādāju un darbu nemeklēju &,- 311 & ,419 & ,458 &, 733 &, 147 & ,264 &, 578 & 1,159 \\
\hline Cits & ,849 & ,477 & 075 & 2,338 & 1,173 & ,323 &, 000 & 3,232 \\
\hline Dzīvesvieta (ref. galvaspilsēta) & & &, 000 & & & &, 000 & \\
\hline Cita lielā pilsēta &,- 471 &, 145 &, 001 & ,624 &,- 387 & ,098 &, 000 & 679 \\
\hline Mazpilsēta &,- 656 &, 159 &, 000 &, 519 &,- 692 &, 104 &, 000 &, 500 \\
\hline Ciemats vai lauku teritorija &,- 953 & ,236 &, 000 &, 386 &,- 940 & , 149 &, 000 & ,391 \\
\hline Amats (ref. nestrādā) & & &, 002 & & & &, 001 & \\
\hline Vadītāji, profesionāḷi &, 541 & ,252 &, 032 & 1,718 &, 598 & , 166 &, 000 & 1,819 \\
\hline $\begin{array}{l}\text { Tirdzniecības un pakalpojumu } \\
\text { darbinieki }\end{array}$ &,- 058 & ,313 &, 852 & ,943 & ,261 & , 195 & ,182 & 1,298 \\
\hline Kvalificēti strādnieki &,- 182 & ,332 &, 584 &, 834 & ,608 & , 190 &, 001 & 1,837 \\
\hline Mazkvalificēti strādnieki & ,409 & ,326 & ,210 & 1,505 & ,349 & ,201 & ,082 & 1,418 \\
\hline $\begin{array}{l}\text { Piederības izjūta Latvi- } \\
\text { jas iedzīvotājiem (ref. lototi } \\
\text { piederīgs (-a)) }\end{array}$ & & &, 182 & & & &, 030 & \\
\hline Zināmā mērā piederīgs (-a) & ,224 & ,143 &, 117 & 1,251 & ,099 & ,099 & ,316 & 1,104 \\
\hline $\begin{array}{l}\text { Ne piederīgs, ne nepie- } \\
\text { derīgs (-a) }\end{array}$ &,- 048 &, 177 &, 787 & ,953 & ,309 &, 116 & ,008 & 1,362 \\
\hline Samērā nepiederīgs (-a) & ,062 & ,206 & ,763 & 1,064 &, 311 &, 136 &, 022 & 1,365 \\
\hline Pilnīgi nepiederīgs (-a) &,- 228 & ,298 & ,443 &, 796 & ,372 & , 188 &, 048 & 1,450 \\
\hline $\begin{array}{l}\text { Piederības izjūta cilvēkiem } \\
\text { no Latvijas ārzemēs (ref. ḷoti } \\
\text { piederīgs (-a)) }\end{array}$ & & &, 000 & & & &, 000 & \\
\hline Zināmā mērā piederīgs (-a) &,- 491 & ,129 &, 000 & ,612 &,- 027 & ,095 & ,777 & ,973 \\
\hline $\begin{array}{l}\text { Ne piederīgs, ne } \\
\text { nepiederīgs (-a) }\end{array}$ & $-1,253$ &, 167 &, 000 & ,286 &,- 687 &, 110 &, 000 &, 503 \\
\hline Samērā nepiederīgs (-a) & $-1,761$ & ,231 &, 000 &, 172 &,- 784 &, 141 &, 000 &, 457 \\
\hline Pilnībā nepiederīgs (-a) & $-1,077$ & ,262 &, 000 &, 341 & $-1,239$ &, 190 &, 000 & ,290 \\
\hline $\begin{array}{l}\text { Cik cieši jūtas saistîts ar Latviju } \\
\text { (ref. l̦oti cieši) }\end{array}$ & & &, 166 & & & &, 000 & \\
\hline Cieši &,- 263 &, 127 &, 038 &, 769 &,- 506 & 086 &, 000 & 603 \\
\hline Ne pārāk &,- 144 &, 165 &, 383 &, 866 &,- 582 &, 108 &, 000 &, 559 \\
\hline Nemaz &, 111 &, 351 & ,751 & 1,118 & $-1,041$ & ,237 &, 000 & ,353 \\
\hline Apmierinātība ar dzīvi kopumā &,- 006 &, 031 &, 858 & ,994 &,- 003 &, 021 &, 880 & ,997 \\
\hline $\begin{array}{l}\text { Atgriešanās plāni (ref. noteikti } \\
\text { neplāno atriezties) }\end{array}$ & & &, 000 & & & &, 000 & \\
\hline
\end{tabular}




\begin{tabular}{|c|c|c|c|c|c|c|c|c|}
\hline & \multicolumn{4}{|c|}{$\begin{array}{c}\text { M1 }(n=7117) \\
\text { Līdzdalība diasporas } \\
\text { organizācijās }\end{array}$} & \multicolumn{4}{|c|}{$\begin{array}{c}\text { M2 }(n=7162) \\
\text { Līdzdalība diasporas } \\
\text { pasākumos }\end{array}$} \\
\hline & B & S. E. & Sig. & $\operatorname{Exp}(B)$ & B & S. E. & Sig. & $\operatorname{Exp}(B)$ \\
\hline $\begin{array}{l}\text { Plāno atgriezties tuvāko } 6 \\
\text { mēnešu laikā }\end{array}$ &,- 477 & ,378 & ,206 &, 620 & ,735 &, 216 & ,001 & 2,085 \\
\hline $\begin{array}{l}\text { Plāno atgriezties tuvāko } 5 \text { gadu } \\
\text { laikā }\end{array}$ & ,440 & ,253 & 083 & 1,552 & 1,031 & ,172 &, 000 & 2,803 \\
\hline Plāno atgriezties vecumdienās & 847 & ,231 &, 000 & 2,332 & 815 & , 162 &, 000 & 2,258 \\
\hline Varbūt, noteiktos apstākḷos & ,715 & ,201 &, 000 & 2,044 &, 589 & ,143 &, 000 & 1,803 \\
\hline Drīzāk neplāno atgriezties &, 381 & ,217 & ,079 & 1,464 & ,472 &, 153 & ,002 & 1,603 \\
\hline $\begin{array}{l}\text { Cik viegli savilkt galus kopā } \\
\text { (ref. ar grūtībām) }\end{array}$ & & &, 000 & & & &, 047 & \\
\hline Ar nelielām grūtībām & $-1,065$ & ,314 & ,001 &, 345 &, 412 & ,301 &, 171 & 1,510 \\
\hline Samērā viegli & $-1,045$ & ,276 &, 000 & ,352 & ,298 & ,262 &, 254 & 1,347 \\
\hline Viegli & $-1,039$ & ,281 &, 000 &, 354 &, 502 & ,243 & ,039 & 1,652 \\
\hline L,oti viegli &,- 913 & ,282 &, 001 & ,401 &, 563 & ,242 &, 020 & 1,755 \\
\hline Nav atbildes & $-2,423$ & ,614 &, 000 &, 089 & ,343 & ,245 &, 161 & 1,409 \\
\hline $\begin{array}{l}\text { Cik daudzi no tuviem draugiem } \\
\text { ir no Latvijas un dzīvo mītnes } \\
\text { zemē (ref. neviens) }\end{array}$ & & &, 000 & & & &, 000 & \\
\hline Viens &, 421 &, 155 &, 007 & 1,524 & ,437 & ,106 &, 000 & 1,548 \\
\hline Divi &, 307 &, 169 & ,069 & 1,360 &, 183 & ,114 &, 109 & 1,201 \\
\hline Trīs vai vairāk & ,614 &, 129 &, 000 & 1,847 &, 547 & ,087 &, 000 & 1,728 \\
\hline $\begin{array}{l}\text { Cik daudzi no tuviem drau- } \\
\text { giem ir vietējie mītnes zemē } \\
\text { (ref. neviens) }\end{array}$ & & &, 039 & & & &, 001 & \\
\hline Viens &, 347 & , 199 &, 081 & 1,415 &,- 011 &, 133 & ,931 & ,989 \\
\hline Divi & ,491 &, 181 &, 007 & 1,634 &, 324 & , 123 & ,008 & 1,383 \\
\hline Trīs vai vairāk & ,209 &, 131 & , 109 & 1,233 & ,279 & ,083 & ,001 & 1,322 \\
\hline Latvijas valstspiederīgais & ,342 & ,182 & ,060 & 1,408 & ,310 &, 154 & ,044 & 1,364 \\
\hline Konstante & $-3,704$ & ,634 &, 000 &, 025 & $-1,157$ & ,457 &, 011 &, 314 \\
\hline
\end{tabular}

Cilvēkiem ar augstāko izglīî̄ibu iespēja darboties diasporas organizācijās ir divas reizes lielāka nekā cilvēkiem ar zemāko izglītības līmeni. Tāpat viņi 1,7 reizes biežāk piedalījušies diasporas pasākumos. Piesaistît mazāk izglītotos diasporas pārstāvjus, vienkārša darba darītājus ir viens no svarīgiem izaicinājumiem, lai nodrošinātu pēc iespējas plašāku diasporas pārstāvniecību. Šobrīd lielāka iespēja iesaistīties diasporas organizācijās vai pasākumos ir vadītājiem un profesionāliem. Kā norāda jaunieši, kas piedalījušies FGD, šobrīd projekti tiek vairāk rakstīti, domājot par intelektuālu mērḳauditoriju. Vienlaikus pētījuma rezultāti liecina, ka aiznemtība darbā var būt būtisks faktors, kas kavē iesaisti diasporas dzīvē.

Motivāciju iesaistīties diasporas organizācijās ietekmē arī atgriešanās plāni. Lielāka iespēja darboties diasporas organizācijās ir tiem, kuri piel̦auj domu par atgriešanos tālākā nākotnē (plāno atgriezties Latvijā vecumdienās vai varbūt varētu atgriezties noteiktos apstākl,os). Tos, kuri neplāno atgriezties, mazāk interesē saiknes uzturēšana ar Latviju, savukārt tie, kas plāno atgriezties jau ļoti drīz, iespējams, neredz jēgu piedalīties diasporas organizācijās. 
Tos, kam nav plānu atgriezties, arī diasporas pasākumi interesē mazāk nekā citus.

Diasporas pasākumu apmeklēšana un iesaiste organizācijās atkarīga arī no sociāliem faktoriem: tā ir izplatîtāka starp diasporas pārstāvjiem, kuriem ir viens vai vairāki draugi no Latvijas mītnes zemē pretstatā tiem, kuriem šãdu draugu nav. Taču arī draudzība ar vietējiem nav škēerslis iesaistei diasporas dzīvē: diasporas pasākumos aktīvāk piedalās tieši tie, kam ir divi vai vairāk vietējo draugu. Tātad plašāks draugu loks drīzāk liecina par sabiedriskumu, kas, kā liecina FGD, var veicināt iesaisti dažāda veida pasākumos ${ }^{8}$.

Tas, ka diasporas organizācijās un pasākumos bieži sastopami vecāki cilvēki, nav izskaidrojams tikai ar salīdzinoši augstāku vecās diasporas aktivitāti. Kā liecina regresiju analīzes rezultāti, pat kontrolējot citu faktoru ietekmi, 65 gadus veciem un vecākiem diasporas pārstāvjiem salīdzinājumā ar jauniešiem ir četras reizes lielāka iespēja iesaistīties diasporas organizācijās un divas reizes lielāka iespēja pēdējā gada laikā apmeklēt diasporas pasākumus. Daḷejji tas skaidrojams ar to, ka pensijā esošajiem mazāks šḳērslis ir laika trūkums. Jauniešiem laika trūkums ir viens no galvenajiem neiesaistīšanās iemesliem, tomēr l̦oti daudzi jaunieši vecumā līdz 35 gadiem (40\%) aptaujā norādījuši, ka vinus tas vienkārši neinteresē. Ja jaunieši plāno palikt uz dzīvi mītnes zemē, viņi mēdz minēt vēlmi asimilēties, nevis palikt latviešu lokā, vēlmi būt starp vietējiem vai ar savu gimeni un draugiem, nevis ar citiem latviešiem un uzturēt latviešu kultūru. Daḷa jauniešu diasporas organizācijās neiesaistās, jo ir vēlme pēc kā jauna, nevis vecā, ierastā. Turklāt ierobežota laika apstāklos diasporas pasākumi konkurē ar citām alternatīvām aktivitātēm, īpaši lielajās pilsētās. Iesaistīšanos kavē arī vienkārši slinkums.

Cits ārkārtīgi biežs iemesls, kādēl, jaunieši neiesaistās diasporas organizācijās, ir informācijas trūkums par tām un par iespējām tajās iestāties. Visās diskusiju vietās ir vērojams, ka dalībnieki (tie, kas paši ir aktīvi diasporas dzīvē) zina vai nu l̦oti daudzas organizācijas viṇu pilsētā, vai arī izteikti maz. To var raksturot kā sava veida "burbuḷa fenomenu", un

8 Mierina, Koroleva 2015. tas skaidro, kādēl dažkārt sastopami pretrun̄̄gi viedokḷi par to, vai informācijas ir maz vai daudz. Jaunieši var nosaukt dažādus diasporas pasākumus, korus, pašdarbības kolektīvus un skoliņas, taču mazāk zina par specifiskām interešu grupām - sarunu klubiem, jauniešu biedrībām, profesionāḷ organizācijām u. c. Par interneta portālu Latviesi.com ir informēts reti kurš jaunietis.

Citiem, savukārt, neiesaistīšanās iemesls ir slikta pieredze saskarsmē ar latviešiem priekšstats, ka latviešu tauta ārzemēs ir negatīva, neuzticama, nesaliedēta, izmanto, aprunā. Studentus arī biežāk nekā citus attur dalības maksa un tas, ka grūti nokḷūt līdz pasākumu norises vietai. Vinu līdzekḷi ir ierobežoti, un personīgā auto parasti nav. Šìs problēmas risināšanā, pēc jauniešu domām, palīdzētu pašiem savas organizācijas izveide vai struktūrvienību izveide dažādās mazākās pilsētās, pasākumu rīkošana savā pilsētā, kā arī kopīgu braucienu organizēšana ar citiem latviešiem.

Tas, ka jaunieši nav iesaistījušies diasporas organizācijās un grupās vai neapmeklē diasporai domātos pasākumus, nenozīmē, ka viņi nevēlas uzturēt saikni ar Latviju. Tieši tas, ka Latvija ir tuvu un viegli sasniedzama, daḷi mazina nepieciešamību speciāli meklēt iespējas satikties ar citiem latviešiem ārvalstīs (labāk aizbraukt uz Latviju ciemos, ja ir laiks). Kvantitatīvā aptauja apliecina, ka lielāka motivācija varētu būt jauniešiem, kuri dzīvo valstīs, kas atrodas tālu no Latvijas, vai kuriem pašiem vairs nav tuvu radinieku vai draugu Latvijā.

\section{Jauniešu priekšstati par diasporas organizācijām}

Atbilstoši aptaujas datiem tieši jaunieši 15-24 gadu vecumā biežāk nekā citi uzskata, ka diasporas organizācijas nav domātas viniem (19\%). FGD ar jauniešiem atklāj, ka tam ir šādi biežākie iemesli:

1. Organizācijas bieži ir noslēgtas - nevienu nepazīstot, atnācis uz pasākumu, jaunietis jūtas neērti, jo jānāk ar savu bariņu; liekas, ka latvieši ir iedomīgi. Lai šăda situācija neveidotos, jaunieši iesaka rīkot pasākumus ar domu, ka nāks nepazīstami cilvēki, ar kuriem ir jāiepazīstas un savstarpēji jākomunicējas. 
2. Formāts - obligāti jābūt biedram, kādā sarakstā - uzliek pienākumu, bet nav paredzams, vai tiešām katru nedēḷu būs iespēja atnākt.

3. Organizācijās darbojas pārsvarā vecāki cilvēki.

4. Vēstniecību pasākumi - l̦oti smalki un formāli.

5. Liela daḷa jauniešu ārvalstīs atrodas tikai uz laiku - kā studenti, tādēl viņu dalība grupās ir neprognozējama, tas arī ietekmē to, kā jauniešus tajās uztver.

Jo īpaši diasporas virsorganizācijas dažkārt škiiet pārāk tālas un formālas. Pārlieka formalitāte, nedabīgums, oficiālums jauniešus attur no iesaistīšanās - jauniešiem ir iespaids, ka latviešu organizācijās tiek veidots neīsts patriotisms, tajās jāizliekas. FGD jaunieši min, ka organizācijās nav vērts iesaistīties, jo tajās ir garlaicīgi, nav viņu interesēm atbilstošu organizāciju vai pasākumu, pulciṇu, tām ir cita mērķauditorija, trūkst dažādības. Diskusiju dalībnieki iesaka biežāk rīkot tādas aktivitātes, kas atbilst jauniešu interesēm un ir mazāk saistītas ar nacionālismu, bet vairāk - ar tīklošanos, kopā būšanu, un domāt par pasākumu satura daudzveidību.

Jauniešiem diasporas organizācijas asociējas, pirmkārt, ar tautiskumu (tautastērps, folklora, tradīcijas, deju kolektīvi, kori, latviešu valodas uzturēšana u. tml.), patriotiskumu un ilgām pēc dzimtenes, un dažādām brīvā laika aktivitātēm (brīvprātīgais darbs, svētki, pasākumi u. c.). Diemžēl visās FGD tiek minētas arī negatīvās asociācijas: iedomīgi latvieši, intrigas, seni kašķi starp cilvēkiem, dzērāji, raudulīgums. Dažkārt, īpaši runājot par virsorganizācijām un citām organizācijām, kas saņem valsts finansējumu, tika izteikts aizdomīgums par to patieso mērḳi un apslēptām politiskām interesēm, turklāt vairākkārt minēts šo organizāciju birokrātiskums. Jauniešu vidū īpaši populārs ir viss, kas ir neatkarīgs, atvērts un dinamisks un pēc iespējas mazāk formāls un birokrātisks. Priekšstats par diasporas organizāciju dalībniekiem jauniešiem lielākoties ir pozitīvs, un nepareizi stereotipi nav iemesls neiesaistîties.

Viens no galvenajiem argumentiem, kas mudina jauniešus iesaistīties diasporas organizācijās un pasākumos, ir iespēja būt kopā ar citiem latviešiem, "savējiem", iepazìt jaunus cilvēkus, iegūt jaunus draugus, arī noderīgus kontaktus dažādās jomās. Dalība diasporas organizācijās remdē ilgas pēc Latvijas un ḷauj nostiprināt saites (gan starp cilvēkiem, gan ar Latviju). Jaunieši novērtē iespēju runāt latviski, uzlabot arī bērnu latviešu valodas zināšanas, izzināt latviešu kultūru un baudīt latviešu ēdienus. Kā argumentu iesaistīties diasporas organizācijās jaunieši saskata arī to, ka tās iekrāso ikdienu, dod iespēju labi pavadīt laiku, piedalīties pasākumos un ceḷot, kā arī lauj pilnveidot prasmes, attīstīt hobijus - dziedāt, dejot utt. - un sniedz pieredzi organizēšanā. Daḷa emigrantu diasporas organizācijās iesaistās, jo uzskata, ka tādējādi paveras iespēja kaut ko uzlabot un izmainīt, kā arī saglabāt bērnībā ierasto gada ritējumu (Jāṇi, 18. novembris u. tml.). Citiem tā ir iespēja satikt cilvēkus, kam bijušas līdzīgas problēmas, konsultēties par sadzīviskiem jautājumiem latviešu dzīvē ārvalstīs. Visas šīs priekšrocības iespējams uzsvērt, lai piesaistītu diasporas organizācijām vairāk jauniešu.

Ideālai organizācijai, pēc jauniešu domām, būtu ne vien jānodarbojas ar kultūras aktivitātēm, bet arī jāsniedz praktiska palīdzība (piem., dokumentu kārtošanā) jauniešiem/māmināām/ tiem, kas nesen pārvākušies uz ārzemēm, jo tā ir aktuāla daudziem. Šāda organizācija būtu spēcīga vadošā komanda ar harismātisku, motivētspējīgu līderi. Ideāla organizācija rīkotu pasākumus (piem., kora uzstāšanos) ne tikai saviem biedriem, bet arī visiem citiem, piem., sarunu klubus, sporta pasākumus (futbols, volejbols, kur sportiskie latvieši spēlē un pārējie skatās vai organizē mačus), tematiskos vakarus (diskusijas, karaoke vakari, filmu vakari, viktorīnas, kulinārijas vakari, makšķerēšanas klubs, šlāgerballes, meistarklases, tirdziṇi, māmiņu klubi, viesi no Latvijas utt.), kā ar̄̄ kopīgus izbraucienus dabā, četrreiz gadā lielākas balles. Brauktu ciemos viesi no Latvijas, organizētu meistarklases, interešu grupas. Rēķinoties ar laika trūkumu un potenciālo dalībnieku aizņemtību, jaunieši iesaka vairāk rīkot tādus pasākumus, kurus varētu apmeklēt kopā ar ǵimeni un kuriem varētu pielāgot dažādus laikus. Ideālā organizācijā dalībnieki iesaistītos aktīvi un regulāri. Tāpat organizācijai būtu vajadzīga mārketinga stratēǵija, lai informētu 
potenciālos biedrus par savu darbību un rīkotajiem pasākumiem, jo svarīgi, lai organizācijāa iesaistītos daudz cilvēku. Lai izveidotu ideālu organizāciju, pēc jauniešu domām, svarīgi, lai būtu vīzija, pieprasījums un degsme. Tā nodrošinātu iespēju labi pavadīt laiku, iegūt jaunus draugus, atpūsties, ceḷot kopā, runāt latviešu valodā un dalīties Latvijas vērtībās. Jaunieši min, ka pašlaik kopām mēdz būt slikti vadītāji, trūkst līderu, taču pašiem pamatā nav vēēěanās uzṇemties vadību.

\section{Secinājumi un ieteikumi}

Latvijas diasporas organizācijās šobrīd iesaistās gandrīz tikai latvieši, turpretī mazākumtautîbu emigrantu, jo īpaši krievu, iesaistīšanās diasporas dz̄ivē ir niecīga. Tas liecina, ka, veidojot pasākumus un uzrunājot diasporu, svarīgi ir atcerēties arī par citu tautību emigrantiem un piedāvāt viniiem saistošas aktivitātes (piem., sporta pasākumus), kas varētu ieinteresēt jebkuras tautības cilvēkus. Šobrīd pat latviešu vidū mākslinieciskās pašdarbības kolektīvu (koru, deju kolektīvu) darbība nav biežākais ārzemēs dzīvojošo kopīgo aktivitāšu veids, taču vispirms tieši ar šādiem kolektīviem asociējas Latvijas diasporas aktivitātes. Kopumā, ņemot vērā, ka ārzemēs dzīvojošie latvieši nereti vēlas aktivitātēs iesaistît arī savus citas tautības dzīvesbiedrus vai draugus, vairāk uzmanības jāpievērš informācijas pieejamībai angḷu (vai mītnes zemes) valodā gan pasākumos, gan interneta vidē (t. sk. organizāciju mājaslapās). Jaunieši, kas piedalījās pētījumā, iesaka mācìt par Latviju arī mītnes zemes izcelsmes cilvēkiem (piem., angḷiem), gatavot materiālus un nest informāciju uz āru, uzsverot, ka gaidīti ir dažādi cilvēki un ka kultūras dienas jārīko kā publiski, visiem atvērti pasākumi. N̦emot vērā, ka daļa pasākumu tiek organizēti vēstniecībās, svarīgi veidot izpratni, ka uz tiem tikpat l,oti ir gaidīti tie, kam nav Latvijas pilsonības.

Plānojot atbalstu diasporas pasākumiem, svarīgi orientēties ne vien uz valstīm ar lielāko diasporas pārstāvju skaitu, bet arī uz valstīm un reǵioniem, kur Latvijas izcelsmes cilvēku ir mazāk un arī piedāvājums ir daudz mazāks, t. i., kur latvietību saglabāt ir grūtāk: Dienvideiropas valstis, Austrumeiropas valstis, NVS valstis un Gruzija. Dalībnieku skaitu pasākumos un organizācijās varētu palielināt arī, biežāk organizējot pasākumus mazpilsētās un lauku reǵionos, organizējot kolektīvu braukšanu uz pasākumiem un pēc iespējas mazinot pasākumu dalības maksu. Lai iesaistītu vairāk mazkvalificēto diasporas pārstāvju, svarīgi, rīkojot pasākumus, neaizmirst arī par vienkāršākiem cilvēkiem - dot iespēju rīkot viktorīnas, karaokes, šlāgerballes, futbolu, velobraucienus, pārgājienus, citas vienkāršas aktivitātes, kurās var piedalīties jebkurš.

Jaunieši biežāk nekā citi uzskata, ka diasporas organizācijas nav domātas viṇiem un ka viņus tās neinteresē. Pēc jauniešu domām, svarīgi, lai organizācija izrāda iniciatīvu, organizē draudzības vakarus, kuros var iepaz̄̄ties, izstāstīt par organizāciju, sniedz atklātu informāciju par organizācijas darbību, uzticas saviem biedriem un iesaista vinus darbībā un pasākumu organizēšanā kopā ar vietējiem. Tagad jauniešiem mēdz būt iespaids, ka organizācijās ir garlaicīgi un ka nav viṇu interesēm atbilstošu organizāciju vai pasākumu, pulciṇu, trūkst dažādības. Kopumā šis rezultāts skaidri norāda uz problēmām pašu organizāciju darbībā, tās nespēj pietiekami pielāgoties jauniešu interesēm. Diskusiju dalībnieki iesaka īstenot vairāk jauniešu interesēm atbilstošu aktivitāšu, kas mazāk saistītas ar nacionālismu, bet vairāk ar tīklošanos, kopā būšanu, kā arī domāt par pasākumu satura daudzveidību un, piem., organizēt arī sporta svētkus, brīvdabas pasākumus un dažādus interešu klubiņus, kas varētu piesaistīt arī tos, kam mazāk interesē latviskā kultūra. Ideālai organizācijai, pēc jauniešu domām, būtu ne vien jānodarbojas ar kultūras aktivitātēm, bet arī jāsniedz praktiska palīdzība cilvēkiem, kas nesen pārvākušies uz ārzemēm. Lai motivētu jauniešus aktīvāk iesaistīties, svarīgi, lai organizācija tiktu vadīta atklāti, būtu atvērta sadarbībai un dotu iespējas jauniešiem, uzklausītu vinu viedokli.

Diskusijās paustais liecina, ka ir svarīgi jaunieti piesaistìt kaut vai vienam pasākumam vai aktivitātei, kuras laikā jaunietis ātri gūst priekšstatu par kopējo latviešu kultūras dzīvi pilsētā, iepazīstas ar citiem vietējiem latviešiem un nonāk dažādās kontaktu listēs vai Facebook grupās. Informācijas aprite pamatā notiek, iesaistoties tîklos, - no viena cilvēka 
pie citiem, no viena pasākuma vai grupas pie citiem. Šādā situācijāa svarīgi būt radošam informācijas izplatīšanā, tîkloties, identificēt tīkla atslēgas personas un izplatît informāciju caur tām, rosinot dalīties ar informāciju par pasākumiem savā draugu un paziņu lokā. Jaunieši uzskata, ka kopumā diasporas organizācijām būtu aktīvāk jāpopularizē sava darbība un ka arī vēstniecība varētu palīdzēt sniegt informāciju par tām. Visbeidzot, jaunieši ierosina izveidot karti, kurā būtu apkopotas visas latviešu organizācijas. Sniedzot atbalstu dažādām diasporas aktivitātēm, jāuzmanās no pārlieku sarežğîtām formalitātēm, kā arī no tā, lai nerastos iespaids par politisko angažētību, kas nāk līdzi finansējumam.

\section{VĒRES}

Goldmanis, M. (2015) Statistisko svaru dizains pētījumā "Latvijas emigrantu kopienas". Mieriṇa, I. (red.) Latvijas emigrantu kopienas: cerību diaspora. Rīga : LU Filozofijas un sociologiijas institūts, 42-65.

Goldsmith, S.; Eggers, W. D. (2004) Governing by Network: The New Shape of the Public Sector. Washington, DC : The Brookings Institution.

Jurkāne-Hobein, I.; Kḷave, E. (2019) Manoeuvring in Between: Mapping Out the Transnational Identity of Russian-Speaking Latvians in Sweden and Great Britain. Kaša, R.; Mierina, I. (eds.) The Emigrant Communities of Latvia: National Identity, Transnational Belonging, and Diaspora Politics. Cham : Springer, 163-182.

Mieriņa, I. (2016) Diasporas līdzdalība un to ietekmējošie faktori. Koṇkova, S. (red.) Kritiskā domāšana, inovācija, konkurētspēja un globalizācija: Tēzes. Rīga : LU Filozofijas un sociologiijas institūts, 65-70.

Mierina, I. (2019) An Integrated Approach to Surveying Emigrants Worldwide. Kaša, R.; Mierina, I. (eds.) The Emigrant Communities of Latvia: National Identity, Transnational Belonging, and Diaspora Politics. Cham : Springer, 13-33.

Mierina, I.; Koroleva, I. (2015) Negotiating identities and friendships while living abroad: Experiences of Latvian migrants. European Scientific Journal, August, 352-368.

Mierina, I.; Ose, L.; Lāce, A.; Kaprāns, M. (2017) Vienojošas nacionālās identitātes un Latvijas kultūrtelpas nostiprināšana: Priekšlikumi sabiedrības integrācijas politikas plānam 2019.-2025. gadam. Pieejams: https://www.km.gov.lv/uploads/ckeditor/files/Sabiedribas_integracija/Petijumi/Ekspertu\%20 zinojums\%20vienojosas\%20nacionalas\%20identitates\%20un\%20kulturtelpas\%20nostiprinasanai.pdf (09.09.2020.). 